\title{
Geography of intestinal permeability and absorption
}

I S Menzies, M J Zuckerman, W S Nukajam, S G Somasundaram, B Murphy, A P Jenkins, R S Crane, G G Gregory

\begin{abstract}
Background-Intestinal morphology and function vary geographically.

Aims-These functions were assessed in asymptomatic volunteers in European, North American, Middle Eastern, Asian, African, and Caribbean countries.

Methods-Five hour urine collections were obtained from each subject following ingestion of a $100 \mathrm{ml}$ iso-osmolar test solution containing $3-0$-methyl-D-glucose, D-xylose, L-rhamnose, and lactulose after an overnight fast, to assess active (3-0methyl-D-glucose) and passive (D-xylose) carrier mediated, and non-mediated (Lrhamnose) absorption capacity, as well as intestinal permeability (lactulose:rhamnose ratio).
\end{abstract}

Results-A comparison of results for subjects from tropical countries $(n=218)$ with those resident in the combined temperate and subtropical region (Europe, United States, Qatar) $(n=224)$ showed significant differences. Residents in tropical areas had a higher mean lactulose:rhamnose ratio and lower mean five hour recoveries of 3-0-methyl-D-glucose, D-xylose, and L-rhamnose, indicating higher intestinal permeability and lower absorptive capacity. Investigation of visiting residents suggested that differences in intestinal permeability and absorptive capacity were related to the area of residence. Subjects from Texas and Qatar, although comprised of several ethnic groups and resident in a subtropical area, showed no significant difference from European subjects.

Conclusions-There are clearly demarcated variations in intestinal permeability and absorptive capacity affecting asymptomatic residents of different geographical areas which correspond with the condition described as tropical enteropathy. Results suggest the importance of environmental factors. The parameters investigated may be relevant to the predisposition of the indigenous population and travellers to diarrhoeal illness and malnutrition. Intestinal function in patients from the tropics may be difficult to interpret, but should take into account the range of values found in the asymptomatic normal population. (Gut 1999;44:483-489)

Keywords: intestinal permeability; absorption; tropical enteropathy; non-invasive sugar absorption/ permeability test
Intestinal morphology and function have been shown to vary geographically. Early studies ${ }^{1-4}$ found that asymptomatic residents of tropical countries in Asia, Africa, and the Caribbean had, compared with indigenous residents of temperate countries, differences in small intestinal mucosal morphology which became referred to as tropical enteropathy. Related studies based largely on absorption of D-xylose and vitamin $B_{12}$ have suggested the presence of an associated subclinical malabsorption. ${ }^{3}$ Little comparative data are available concerning intestinal permeability and absorptive capacity in subjects resident throughout the world using current methods of assessment. These functions can be studied simultaneously by measuring non-mediated permeation and mediated transport of carbohydrates using non-invasive multiple sugar tests. ${ }^{5-10}$

In order to classify intestinal absorption and permeability with respect to residence in different geographical areas, these functions were assessed in asymptomatic indigenous volunteers resident in the United States, and European and tropical countries. Visiting residents were also studied to assess the importance of ethnic factors. We used the oral administration of a multiple sugar solution to assess active (3-0-methyl-D-glucose) and passive (D-xylose) carrier mediated, and nonmediated (L-rhamnose) absorptive capacity as well as intestinal permeability (lactulose:rhamnose ratio)..$^{5-8}$ All urine samples from these "apparently normal" subjects resident in various countries on several continents were analysed by the same laboratory team.

\section{Methods}

STUDY POPULATIONS

Apparently healthy indigenous volunteers (especially selected without gastrointestinal symptoms) were investigated. A total of 442 indigenous volunteers was studied; 218 were resident in tropical areas and 224 in temperate or subtropical areas (see table 1). A group of 30 adult white subjects with professional backgrounds from the UK were also studied while visiting tropical areas such as Papua New Guinea $(n=6)$, Botswana $(n=5)$, South India $(n=13)$, and Gambia $(n=6)$.

INTESTINAL PERMEABILITY AND ABSORPTION TEST PROCEDURE

Complete five hour urine collections into bottles containing preservative were obtained from each subject following ingestion of a 100

Abbreviations used in this paper: GDP, gross domestic product.
Dr Zuckerman.

Accepted for publication 15 October 1998 
Table 1 Field studies undertaken

\begin{tabular}{|c|c|c|c|c|c|}
\hline Area & Latitude & Climate & Subjects & Date & Organisers \\
\hline UK: London & $51.5^{\circ} \mathrm{N}$ & Temperate & Adult whites with professional backgrounds $(n=68)$ & $1979-90$ & $\begin{array}{l}\text { I Menzies, C Noone, N Fox, } \\
\text { G Houston, S Catt }\end{array}$ \\
\hline $\begin{array}{l}\text { Greece: Athens } \\
\text { Northern Italy: }\end{array}$ & $38^{\circ} \mathrm{N}$ & Temperate & Adult whites with professional backgrounds $(n=32)$ & $1986-87$ & T Kakourou \\
\hline $\begin{array}{l}\text { Parma } \\
\text { Texas: El Paso, }\end{array}$ & $45^{\circ} \mathrm{N}$ & Temperate & Adult white hospital staff and relatives $(\mathrm{n}=18)$ & 1987 & C Cafarelli \\
\hline $\begin{array}{l}\text { SW United } \\
\text { States }\end{array}$ & $31^{\circ} \mathrm{N}$ & $\begin{array}{l}\text { Semi-desert, alt. } \\
3700 \mathrm{ft}\end{array}$ & $\begin{array}{l}\text { Adult Hispanics and non-Hispanic whites, professional } \\
\text { background }(n=74)\end{array}$ & $1990-91$ & M Zuckerman, N Casner \\
\hline Qatar: Doha & $25^{\circ} \mathrm{N}$ & $\begin{array}{l}\text { Very arid limestone } \\
\text { desert }\end{array}$ & $\begin{array}{l}\text { Arab and Indian adult professionals, mostly hospital } \\
\text { staff }(n=32)\end{array}$ & 1993 & I Menzies \\
\hline Thailand: Mahidol & $14^{\circ} \mathrm{N}$ & $\begin{array}{l}\text { Tropical, rainfall } \\
\text { moderate }\end{array}$ & Adult Thai hospital staff $(n=25)$ & $\begin{array}{l}1985 \\
1986\end{array}$ & $\begin{array}{l}\text { M Molyneux } \\
\text { N Fox, G Houston }\end{array}$ \\
\hline $\begin{array}{l}\text { S. India: Vellore } \\
\text { Dindigul }\end{array}$ & $13^{\circ} \mathrm{N}$ & $\begin{array}{l}\text { Tropical, rainfall } \\
\text { moderate }\end{array}$ & Adult Indian hospital staff and their relatives $(n=41)$ & $\begin{array}{l}1983-85 \\
1993\end{array}$ & $\begin{array}{l}\text { C Noone, I Menzies } \\
\text { SG Somasundaram }\end{array}$ \\
\hline Indonesia: Jakarta & $6^{\circ} \mathrm{S}$ & $\begin{array}{l}\text { Tropical, rainfall } \\
\text { high }\end{array}$ & $\begin{array}{l}\text { Adult Indonesians, ferry-boat crew and hospital staff } \\
(\mathrm{n}=24)\end{array}$ & 1986 & C Peacock, H Scofield, R Behrens \\
\hline Papua New & & & & & \\
\hline $\begin{array}{l}\text { Guinea, West } \\
\text { Sepik Province }\end{array}$ & $5^{\circ} \mathrm{N}$ & $\begin{array}{l}\text { Tropical, rainfall } \\
\text { high }\end{array}$ & $\begin{array}{l}\text { Juvenile inland rural villagers, aged } 8 \text { to } 18 \text { years, } \\
\text { Krissa Village }(n=11) \text {; Bewani School }(n=6)\end{array}$ & 1979 & Staff of "Operation Drake" \\
\hline Uganda & $3^{\circ} \mathrm{N}$ & $\begin{array}{l}\text { Equatorial, alt. } \\
>3000 \mathrm{ft} \text {, rainfall } \\
\text { moderate }\end{array}$ & $\begin{array}{l}\text { Adult Africans: first group: hospital staff }(n=13) \text {; } \\
\text { second group: of varied socioeconomic status, } \\
\text { documented HIV negative }(n=17)\end{array}$ & $\begin{array}{l}1988 \\
1995\end{array}$ & $\begin{array}{l}\text { L Grellier, E Patterson } \\
\text { B Murphy }\end{array}$ \\
\hline Cameroon & $5^{\circ} \mathrm{N}$ & $\begin{array}{l}\text { Tropical, rainfall } \\
\text { high }\end{array}$ & Adult African university students $(n=17)$ & 1986 & S Nukajam \\
\hline Gambia & $13^{\circ} \mathrm{N}$ & $\begin{array}{l}\text { Tropical, rainfall } \\
\text { moderate }\end{array}$ & Adult Africans, largely hospital staff $(n=24)$ & 1984 & B Slavin \\
\hline Botswana & $23^{\circ} \mathrm{S}$ & $\begin{array}{l}\text { Tropical, } \\
\text { semi-desert, alt. } \\
>3000 \mathrm{ft}\end{array}$ & Adult African hospital staff $(\mathrm{n}=16)$ & 1987 & R Chasty, P Elliot \\
\hline Jamaica: Kingston & $18^{\circ} \mathrm{N}$ & $\begin{array}{l}\text { Tropical, rainfall } \\
\text { high }\end{array}$ & Adult hospital staff of mixed ethnic origin $(n=14)$ & 1986 & G Houston \\
\hline
\end{tabular}

$\mathrm{ml}$ test solution containing 3-0-methyl-Dglucose $(0.2 \mathrm{~g})$, D-xylose $(0.5 \mathrm{~g})$, L-rhamnose (1.0 g) (Sigma Chemical Co., Poole, Dorset, UK), and lactulose $(5.0 \mathrm{~g}=7.5 \mathrm{ml}$ lactulose syrup, $67 \%$ wt/vol, Duphar Laboratories Ltd, West End, Southhampton, UK) after an overnight fast and bladder emptying. Medications and alcohol were excluded from 12 hours before until the end of each test; food and nutritious drinks were excluded from four hours before until two hours after taking the test solution. The test sugars were prepared as a concentrated syrup ( $>2000 \mathrm{mmol} / \mathrm{kg})$, which is resistant to bacterial degradation without refrigeration, for transfer to the field sites. Immediately before use, $10 \mathrm{ml}$ of this syrup (containing a single dose) was dispensed with a syringe and diluted to $100 \mathrm{ml}$ with drinking water to give an approximately iso-osmolar solution $(300 \mathrm{mmol} / \mathrm{kg})$.

The volume of each urine collection was recorded and a $10 \mathrm{ml}$ aliquot, preserved with thiomerasol $(>10 \mathrm{mg} / 100 \mathrm{ml}),{ }^{11}$ was sent for sugar analysis to St Thomas's Hospital, London, where they were processed within four months using the same analytical technique, undertaken or supervised by the same person (ISM).

The study was approved by the Ethics Committee of St Thomas's Hospital, London, UK, and by the Texas Tech University Health Sciences Center Institutional Review Board in El Paso, Texas. All subjects in the study gave informed consent.

\section{ANALYTICAL METHODS}

Test sugars in urine were measured by quantitative thin layer chromatrography using a modification $^{12}$ of a previously described method. ${ }^{13}$ Following development, and a 4-aminosalicyclic/orthophosphoric acid colour reaction, scanning densitometry was undertaken using either a Chromoscan (Joyce-Loebl \& Co., Durham) or BioRad model G57670 Molecular Analyst (BioRad Systems, USA). Sugar concentrations were derived by comparing the optic densities of test zones with a standard concentration curve plotted from standard zones run on the same chromatogram.

Table 2 Absorption and permeability in asymptomatic subjects residing in major geographical areas

\begin{tabular}{|c|c|c|c|c|c|c|}
\hline \multirow[b]{2}{*}{ Area } & \multirow[b]{2}{*}{ Number } & \multicolumn{4}{|c|}{ Excretion of ingested test sugars in urine } & \multirow[b]{2}{*}{$L: R$ ratio } \\
\hline & & $\begin{array}{l}\text { 3-m-glucose } \\
\text { (\% of dose) }\end{array}$ & $\begin{array}{l}\text { D-xylose } \\
\text { (\% of dose) }\end{array}$ & $\begin{array}{l}\text { L-rhamnose } \\
\text { (\% of dose) }\end{array}$ & $\begin{array}{l}\text { Lactulose } \\
\text { (\% of dose) }\end{array}$ & \\
\hline \multicolumn{7}{|l|}{ Temperate } \\
\hline \multicolumn{7}{|l|}{ Non-tropical } \\
\hline European & 118 & $50.0(0.9)$ & $31.2(0.6)$ & $10.0(0.3)$ & $0.298(0.012)$ & $0.031(0.001)$ \\
\hline \multicolumn{7}{|l|}{ Subtropical } \\
\hline North American (Texas, USA) & 74 & $49.3(1.3)$ & $34.7(0.8)$ & $9.2(0.3)$ & $0.346(0.025)$ & $0.037(0.002)$ \\
\hline Middle Eastern (Qatar) & 32 & $45.3(1.9)$ & $33.2(1.2)$ & $10.3(0.5)$ & $0.272(0.014)$ & $0.028(0.002)$ \\
\hline Total & 224 & $49.1(0.7)$ & $32.6(0.5)$ & $9.8(0.2)$ & $0.310(0.011)$ & $0.033(0.001)$ \\
\hline \multicolumn{7}{|l|}{ Tropical } \\
\hline Asian & 107 & $41.7(1.2)$ & $24.2(0.8)$ & $6.0(0.2)$ & $0.385(0.024)$ & $0.075(0.006)$ \\
\hline African & 97 & $47.0(1.3)$ & $26.1(0.7)$ & $6.4(0.2)$ & $0.345(0.031)$ & $0.059(0.006)$ \\
\hline Total $^{\star}$ & 218 & $44.8(0.9)$ & $25.1(0.5)$ & $6.2(0.2)$ & $0.369(0.019)$ & $0.066(0.004)$ \\
\hline
\end{tabular}

Results for sugar excretion expressed as mean (SEM) in five hours.

* Combined tropical group including Jamaica. 


\begin{tabular}{|c|c|c|c|c|}
\hline & $\begin{array}{l}\square \text { 3-m-glucose } \\
\square \text { D-xylose } \\
\text { (\% of dose in } \\
5 \text { h urine) } \\
20 \% \quad 40 \% \quad 60 \%\end{array}$ & 3-m-glucose & D-xylose & L-rhamnose \\
\hline 1 UK (London) $(\mathrm{n}=68)$ & 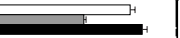 & $51.3(1.2)$ & $33.1(0.7)$ & $11.1(0.4)$ \\
\hline 2 Greece $(n=32)$ & 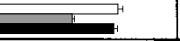 & $46.3(1.8)$ & $28.3(1.1)$ & $8.9(0.5)$ \\
\hline 3 Italy $(\mathrm{n}=18)$ & 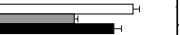 & $51.9(2.6)$ & $29.4(1.5)$ & $7.9(0.6)$ \\
\hline 4 USA (Texas) $(n=74)$ & 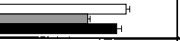 & $49.3(1.3)$ & $34.7(0.8)$ & $9.2(0.3)$ \\
\hline 5 Qatar $(\mathrm{n}=32)$ & H & $45.3(1.9)$ & $33.1(1,3)$ & $10.3(0.5)$ \\
\hline 6 Thailand $(\mathrm{n}=25)$ & ${ }_{4}^{+}$ & $38.4(2.8)$ & $26.7(1.8)$ & $7.1(0.5)$ \\
\hline 7 India $(n=41)$ & $2+\frac{14}{4}$ & $45.8(1.8)$ & $25.9(1.0)$ & $6.0(0.3)$ \\
\hline 8 Indonesia ( $\mathrm{n}=24$ ) & 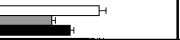 & $39.5(2.5)$ & $21.4(1.3)$ & $5.6(0.4)$ \\
\hline 9 New Guinea $(n=17)$ & 4 & $39.5(3.2)$ & $20.2(2.1)$ & $4.5(0.5)$ \\
\hline 10 Uganda $(n=40)$ & $2+4$ & $44.3(1.5)$ & $24.7(1.0)$ & $6.5(0.3)$ \\
\hline 11 Cameroon $(n=17)$ & 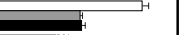 & $56.2(2.3)$ & $32.2(1.0)$ & $6.5(0.4)$ \\
\hline 12 Gambia (n=24) & +4 & $40.6(3.2)$ & $24.6(1.9)$ & $6.2(0.6)$ \\
\hline 13 Botswana $(n=16)$ & $2+\frac{1}{4}$ & $53.9(3.1)$ & $25.4(1.0)$ & $6.1(0.5)$ \\
\hline 14 Jamaica $(n=14)$ & +4 & $52.2(2.3)$ & $24.6(1.4)$ & $7.6(0.7)$ \\
\hline Coeliac discase (untreated) $(n=19)$ & $\frac{1+1}{-1-1}$ & $32.5(4.0)$ & $15.2(1.6)$ & $4.1(0.5)$ \\
\hline \multirow[t]{2}{*}{ Tropical Sprue (untreated) ( $(\mathrm{n}=14)$} & $\frac{1}{1+1}$ & $35.0(4.3)$ & $12.1(1.6)$ & $3.5(0.8)$ \\
\hline & $\begin{array}{l}4.0 \% \quad 8.0 \% \quad 12.0 \% \\
\text { L-rhamnose } \\
\text { (\% of dose in } \\
5 \mathrm{~h} \text { urine) }\end{array}$ & & & \\
\hline
\end{tabular}

Figure 1 Monosaccharide absorption in "healthy" residents.

Results were expressed as percentages of test dose recovered in each five hour urine collection.

STATISTICS

Results in each group are expressed as mean (SEM). Analyses of mean excretion of sugars and mean lactulose:rhamnose ratios between groups were performed using one way ANOVA

\begin{tabular}{|c|c|c|c|}
\hline & 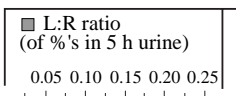 & Lactulose & $\mathrm{L}: \mathrm{R}$ ratio \\
\hline $1 \overline{U K}($ London) $(\mathrm{n}=68)$ & 7 & $0.281(0.014)$ & $0.026(0.001)$ \\
\hline 2 Greece $(n=32)$ & 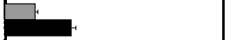 & $0.334(0.025)$ & $0.038(0.002)$ \\
\hline 3 Italy $(n=18)$ & 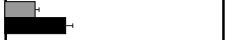 & $0.296(0.038)$ & $0.038(0.004)$ \\
\hline 4 USA (Texas) (n=74) & 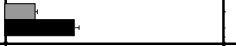 & $0.346(0.025)$ & $0.037(0.002)$ \\
\hline 5 Qatar $(n=32)$ & 7 & $0.272(0.014)$ & $0.028(0.002)$ \\
\hline 6 Thailand $(n=25)$ & + & $0.358(0.043)$ & $0.054(0.006)$ \\
\hline 7 India $(n=41)$ & E & $0.335(0.026)$ & $0.059(0.005)$ \\
\hline 8 Indonesia $(\mathrm{n}=24)$ & & $0.345(0.042)$ & $0.065(0.009)$ \\
\hline 9 New Guinea $(n=17)$ & t- & $0.601(0.096)$ & $0.156(0.024)$ \\
\hline 10 Uganda $(n=40)$ & + & $0.303(0.021)$ & $0.049(0.004)$ \\
\hline 11 Cameroon $(n=17)$ & F & $0.330(0.042)$ & $0.051(0.006)$ \\
\hline 12 Gambia $(n=24)$ & - & $0.527(0.110)$ & $0.096(0.020)$ \\
\hline 13 Botswana $(n=16)$ & ? & $0.192(0.020)$ & $0.033(0.003)$ \\
\hline 14 Jamaica $(n=14)$ & + & $0.415(0.083)$ & $0.054(0.010)$ \\
\hline Coeliac disease (untreated) $(n=19)$ & + & $0.770(0.123)$ & $0.244(0.055)$ \\
\hline \multirow[t]{2}{*}{ Tropical spruc (untreated) $(n=14)$} & $\underline{\pi}$ & $0.520(0.091)$ & $0.200(0.059)$ \\
\hline & \begin{tabular}{|c|}
$0.2 \% 0.4 \% 0.6 \% 0.8 \% 1.0 \%$ \\
Lactulose \\
$(\%$ of dose in $5 \mathrm{~h}$ urine)
\end{tabular} & & \\
\hline
\end{tabular}

Figure 2 Intestinal permeability in "healthy" residents.
( $F$ test) and subsequent multiple comparisons using the Duncan multiple range procedure and Tukey's pairwise comparison procedure. Differences between some groups were also assessed with the Wilcoxon rank sum test. Analyses were performed using the BMDP software (BMDP Statistical Software, Inc., Los Angeles, California, USA). Statistical significance was set at $\mathrm{p}<0.05$ (two tailed tests).

\section{Results}

SUBJECTS

Table 1 presents information about the latitude and climate of the 14 countries in which field studies were undertaken, and the study groups involved.

URINARY EXCRETION OF TEST SUGARS

Figure 1 presents mean absorption of 3-0methyl-D-glucose, D-xylose, and L-rhamnose for subjects resident in each country, expressed as percentage of oral dose recovered in five hour urine; intestinal uptake of lactulose and lactulose:rhamnose permeation ratios are given in fig 2. For comparison, previously reported data from patients with coeliac disease ${ }^{5}$ and with tropical sprue ${ }^{6}$ are provided. Results are grouped by region in table 2 .

Monosaccharide excretion values for indigenous residents in European, North American (United States), Middle Eastern (Qatar), and tropical countries present an approximately normal distribution, and those for lactulose and lactulose:rhamnose ratio approximated to a normal distribution after log transformation.

Comparison of tropical with temperate residents Residents in El Paso, Texas, and Doha, Qatar, which are relatively affluent communities with good sanitation situated in arid semitropical areas, show no significant difference from those resident in temperate European countries (table 2), except for the finding of a slightly higher excretion of $\mathrm{D}$-xylose in Texas $(\mathrm{p}<0.01)$.

An analysis comparing results of all residents from tropical countries $(n=218)$ with those of residents in the combined temperate and subtropical region (Europe, United States, Qatar) ( $n=224)$ using a non-parametric test (Wilcoxon rank sum test) (table 2) indicated significant differences. Residents in tropical areas have a higher intestinal lactulose:rhamnose permeation ratio $(0.066(0.004)$ versus 0.033 (0.001), $\mathrm{p}<0.001)$ and lower five hour recoveries of $3-0-$ methyl-D-glucose (44.8 $(0.9) \%$ versus $49.1(0.7) \%, \mathrm{p}<0.005)$, D-xylose (25.1 (0.5)\% versus $32.6(0.5) \%, \mathrm{p}<0.001)$, and L-rhamnose $(6.2 \quad(0.2) \%$ versus 9.8 $(0.2) \%, p<0.001)$. The difference in lactulose permeation was not significant $(0.369$ $(0.019) \%$ versus $0.310(0.011) \%, p=0.2)$.

The differences in the lactulose:rhamnose permeation ratio and monosaccharide absorption between tropical and temperate resident groups remain significant even when the two most abnormal tropical countries, New Guinea and Gambia, are excluded from the statistical analysis. 


\begin{tabular}{|c|c|c|c|c|c|}
\hline & \begin{tabular}{|l|}
$\square$ Lactulose \\
\\
(\% of dose in \\
$5 \mathrm{~h}$ urine) \\
$0.2 \% 0.4 \% 0.6 \%$ \\
\end{tabular} & \begin{tabular}{|l}
$\square$ L:R ratio \\
(of \%'s in \\
$5 \mathrm{~h} \mathrm{urine)}$ \\
0.020 .040 .060 .08 \\
\end{tabular} & \begin{tabular}{|l|} 
Lactulose \\
(\% of dose)
\end{tabular} & \begin{tabular}{|l|} 
Rhamnose \\
(\% of dose)
\end{tabular} & \begin{tabular}{|l|} 
L:R ratio \\
(\% of dose)
\end{tabular} \\
\hline Ethnic whites & - & $\Leftrightarrow$ & & , & \\
\hline IJK $(\mathrm{n}=68)$ & in & $\Longrightarrow$ & $0.281(0.014)$ & $11.1(0.4)$ & $0.026(1.001)$ \\
\hline New Guinea $(n=6)$ & 1 & $\Longrightarrow$ & $0.251(0.041)$ & $5.9(0.2)$ & 0.042 (11.006) \\
\hline Botswana $(\mathrm{n}=5)$ & 1 & \begin{tabular}{|l|l} 
\\
\end{tabular} & $0.314(0.067)$ & $6.7(1.6)$ & $0.049(0.007)$ \\
\hline Southern India ( $\mathrm{n}=13$ ) & كـ & $\Longrightarrow$ & $0.334(0.081)$ & $6.2(0.6)$ & $0.063(0.018)$ \\
\hline Gambia $(n=6)$ & & & $0.463(0.102)$ & $8.2(0.9)$ & $0.053(0.006)$ \\
\hline \multicolumn{6}{|l|}{ Ethnic Indians } \\
\hline Southern India $(n=41)$ & 1 & 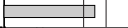 & $0.335(0.026)$ & $6.0(0.3)$ & $0.059(0.0015)$ \\
\hline \multirow[t]{2}{*}{ Qatar $\{n=13\}$} & || & $\Longrightarrow$ & $0.272(0.016)$ & $10.3(0.9)$ & $0.029(1,003)$ \\
\hline & $\begin{array}{l}4.0 \% 8.0 \% 12.0 \% \\
\text { Rhamnose } \\
\text { (\% of dose in } \\
5 \mathrm{~h} \text { urine) }\end{array}$ & & & & \\
\hline
\end{tabular}

Figure 3 Intestinal absorption and permeability of specific ethnic groups resident in different geographical regions.

\section{Ethnic factors}

Intestinal absorption and permeability of white UK residents visiting Papua New Guinea, Botswana, India, and Gambia $(n=30)$ were significantly different (Wilcoxon rank sum test) than for indigenous white UK residents $(n=68)$; urinary excretion of 3-0-methyl-D-glucose $(40.4$ (3.7)\%, p<0.005), D-xylose (22.7 (1.9)\%, $\mathrm{p}<0.001)$, and L-rhamnose $(6.6 \quad(0.4) \%$, $\mathrm{p}<0.001)$ were lower and lactulose:rhamnose ratios higher $(0.055(0.008), \mathrm{p}<0.001)$ for those residing in the tropical areas (fig 3). Furthermore, the reverse was true for ethnic Indians resident in Qatar $(n=13)$, who had significantly higher urinary recovery of D-xylose (33.9 (2.1)\%, p<0.001) and L-rhamnose $(10.3$ $(1.0) \%, p<0.001)$ and a lower lactulose:rhamnose ratio $(0.029$ (0.003), $\mathrm{p}<0.001)$ than the indigenous Indians in India $(n=41)$ (fig 3$)$. With regard to different ethnic groups resident in the same area, no significant differences were found between Hispanics $(n=55)$ and non-
Hispanic whites $(n=19)$ resident in El Paso, Texas, or between Indians $(n=13)$ and nonIndians $(n=19)$ resident in Doha, Qatar.

Differences in affluence: correlation of intestinal function with gross domestic product per capita for country of residence

A rough measure of gross domestic product per capita (GDP) for each country ${ }^{14}$ was used to determine whether there is a relation of this variable with intestinal absorptive capacity and permeability (Spearman rank correlation, two tailed test). A significant positive association of GDP with absorptive capacity was found, and a negative association with lactulose:rhamnose permeability (fig 4). Thus a lower GDP was associated with lower recoveries of $\mathrm{D}$-xylose $\left(r_{\mathrm{s}}=0.72, \mathrm{p}<0.01\right)$ and L-rhamnose $\left(r_{\mathrm{s}}=0.76\right.$, $\mathrm{p}<0.01)$, and with higher lactulose:rhamnose ratios $\left(r_{\mathrm{s}}=-0.77, \mathrm{p}<0.01\right)$.

\section{Possible importance of HIV infection}

Urinary recoveries of 3-0-methyl-D-glucose, D-xylose, and L-rhamnose, and lactulose:rhamnose ratios from HIV negative Ugandan residents (1995, $\mathrm{n}=27$ : $43.2(1.6) \%, 25.6$ (1.1) \%, $6.6(0.4) \%$, and $0.049(0.004))$ and a group studied earlier in which HIV status had not been investigated (1988, $\mathrm{n}=13$ : 46.5 (3.2) \%, $22.9(2.1) \%, 6.4(0.6) \%$, and 0.048 $(0.004))$ showed no significant differences (Wilcoxon rank sum test).

Sensitivity of different test monosaccharideslinear discriminant analysis

Our results indicate that depression of L-rhamnose is most and 3-0-methyl-D-glucose least in the tropical compared with the European group. Excretion of 3-0-methyl-Dglucose, D-xylose, and L-rhamnose is reduced by $10.4 \%, 19.6 \%$, and $38.0 \%$, respectively, in

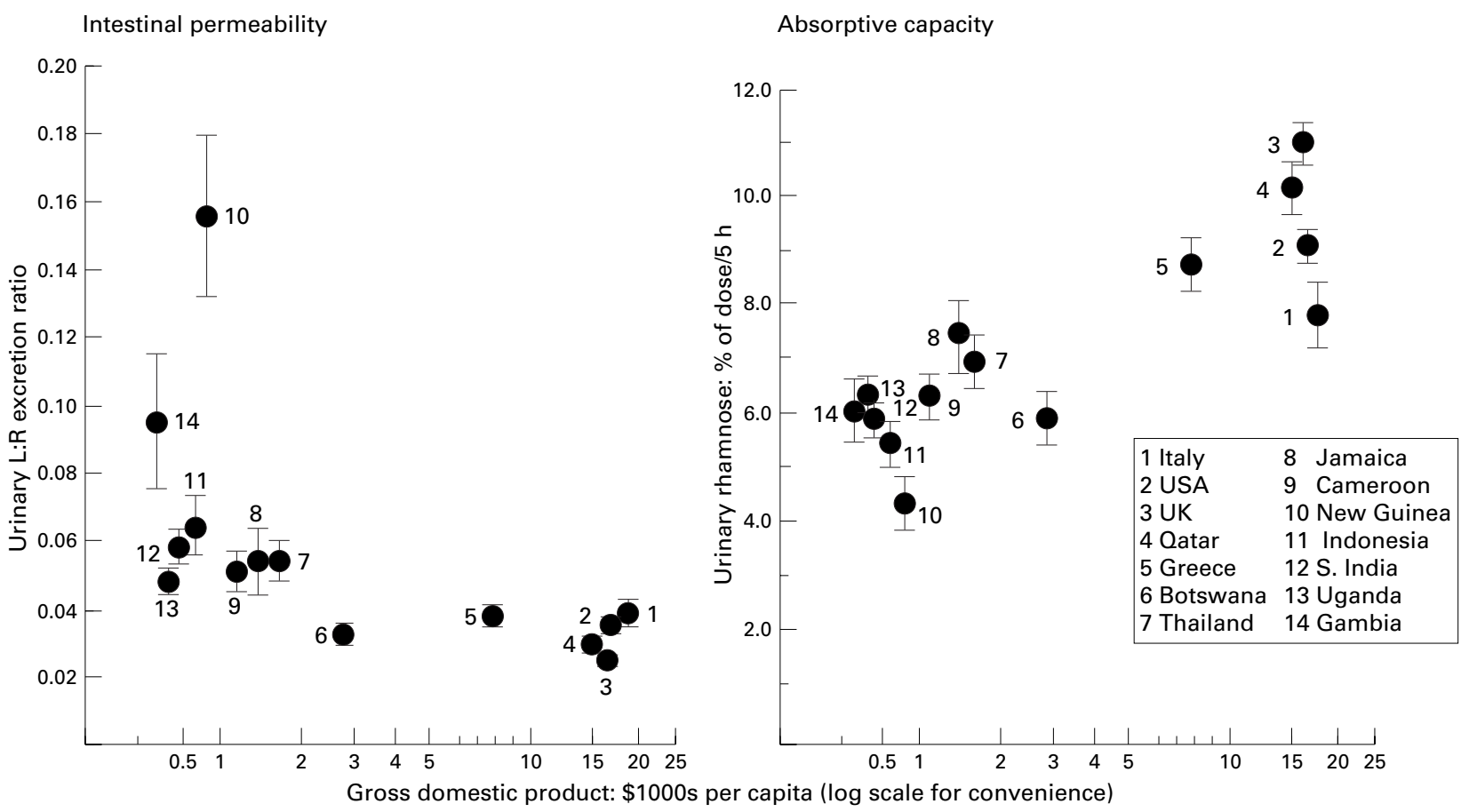

Figure 4 Correlation of intestinal permeability and absorptive capacity with gross domestic product per capita for country of residency plotted on a log scale. 
the tropical group. A separate analysis of variance concerning the differences in logarithms of the three monosaccharides confirms that these percentage differences are significant $(p<0.001)$. Stepwise linear discriminant analysis indicates that L-rhamnose is most significant for discriminating between the European and tropical groups, and the $F$ statistics for entering the other sugars are very small, implying that 3-0-methyl-D-glucose and D-xylose do not provide any additional discriminatory power.

\section{Discussion}

Geographical variation in intestinal mucosal morphology was originally described in studies of intestinal structure using peroral jejunal biopsy specimens in tropical countries in the 1960s and 1970s. ${ }^{34}$ Studies from Thailand, ${ }^{1}$ Pakistan, ${ }^{15}$ Haiti and Puerto Rico, ${ }^{16}{ }^{17}$ Nigeria, ${ }^{18}$ and other countries in Asia, Africa, and the Caribbean ${ }^{219}$ showed a high prevalence of altered villus architecture (villus atrophy) and cellular infiltration of the lamina propria in asymptomatic residents of tropical areas. As with native born residents, long term travellers (more than six months) visiting tropical countries such as Pakistan and Vietnam showed mucosal abnormalities and subnormal xylose absorption, ${ }^{13} 2021$ and immigrants from India and the Caribbean without diarrhoeal illness resident in the UK also had minor changes in small bowel morphology (decreased mucosal thickness, villus height, villus/crypt ratios, and enterocyte height) compared with indigenous white residents. ${ }^{22}{ }^{23}$ Such mucosal abnormalities, usually associated with impaired D-xylose absorption, were referred to as tropical enteropathy. Abnormal xylose absorption and jejunal villus architecture in subjects emigrating from the Caribbean, ${ }^{24}$ India, and Pakistan ${ }^{25}$ have been reported reversible with increasing length of residence in the temperate climate of New York, USA.

Previous investigations of intestinal function in tropical countries have been criticised for relying on the use of the D-xylose test, especially regarding the impact of variables such as small bowel bacterial overgrowth and inexact urine collection. ${ }^{1526}$ Limitation of absorption to the jejunum ${ }^{27}$ and susceptibility of this pentose to hepatic metabolism also complicate interpretation of this test. The effect of non-mucosal variables (for example, ingestion, gastric emptying, intestinal transit, renal clearance, and urine collection) can be reduced by simultaneous use of a combination of test probes. ${ }^{5-10}$ For the present project, which seems to be the first large scale multinational application of a differential absorption technique, urinary excretion of lactulose and L-rhamnose together with D-xylose and 3-0-methyl-D-glucose ${ }^{679}$ was measured to assess small intestinal permeability (barrier function) together with mediated and nonmediated monosaccharide uptake (absorptive function). The study was undertaken to investigate the association of altered intestinal function in apparently healthy subjects residing in a wide range of geographical locations including the tropics. It contributes to this area of research with respect to the technique used for assessing severity of intestinal dysfunction in the field, and to the range of geographical areas covered.

Significant geographical variations were shown, normal residents in most tropical areas having higher urinary lactulose:rhamnose ratios and lower recovery of L-rhamnose, D-xylose, and 3-0-methyl-D-glucose, than those resident in temperate and subtropical areas, indicating increased intestinal permeability and reduced absorptive capacity in asymptomatic tropical residents. These findings extend those of more limited studies reported previously. In Sudan, increased intestinal lactulose/mannitol permeation was found in 10 apparently healthy residents compared with 33 normal subjects from the $\mathrm{UK}^{26}$; in Israel, ${ }^{28}$ a wide range of ${ }^{51} \mathrm{Cr}$-EDTA permeation was found in control subjects which may reflect the presence of tropical enteropathy in the Middle East. Asymptomatic subjects from India and the Carribean resident in Birmingham, UK, showed a higher lactulose/mannitol excretion than resident white subjects, ${ }^{23}$ which accorded with intestinal morphology. ${ }^{22}$ As the ethnic groups mentioned were not studied while resident in both temperate and tropical countries, comparisons required to establish the aetiological importance of ethnic versus geographical factors were not possible.

The causes of geographical variation in intestinal permeability and absorptive capacity are most likely environmental. Although the current study was not designed to determine the cause of tropical enteropathy, our limited data from "visiting residents" of different ethnicity, mainly British white subjects tested while resident in tropical countries and Indian subjects resident in Qatar, suggests that both permeability and absorptive capacity correspond to the country of residence rather than of origin (see fig 3), being consistent with an environmental rather than an ethnic aetiology. Previously mentioned studies of mucosal morphology and function in immigrants and visitors from tropical to temperate areas have also been interpreted as being consistent with the importance of environmental factors. ${ }^{22-25}$ Although some abnormal results from the latter studies could be related to ethnic origin, the duration of uninterrupted residency in a temperate area that elapsed before the investigation should be taken into account. This raises a question concerning the duration for which tropical enteropathy may persist.

As postulated in early studies of tropical enteropathy, exposure to microorganisms in settings of poor hygiene and sanitation with repeated, often subclinical episodes of enteric infection due to a variety of viral, bacterial, and protozoal pathogens or changes in gut microbial flora are probably responsible. ${ }^{29202125}$ Intestinal permeability assessed by differential urinary sugar excretion ${ }^{29-32}$ or ${ }^{51} \mathrm{Cr}-\mathrm{EDTA}^{33}{ }^{34}$ is known to be increased in patients with diarrhoea due to such infections. The possibility that increased intestinal permeability and reduced absorption currently seen in some tropical areas may be due to HIV infection also 
needs to be considered as such changes have also been described in this condition, ${ }^{35} 36$ usually in association with diarrhoea. Determination of HIV serological status was not part of the protocol as most of the studies preceded the main pandemic, but the absence of significant differences between the recent (1995) HIV negative and the previous (1988) unclassified group of Ugandan residents reinforces the suggestion that HIV infection is not an important aetiological factor for tropical enteropathy in symptomless subjects.

Socioeconomic status also seems to be an important variable, ${ }^{14}$ abnormal intestinal function (see fig 4) and structure being associated with lower economic status. It should be emphasised, however, that our study mainly concerned somewhat affluent individuals, results suggesting that they also are susceptible to the impact of gross national product along with the community in general. Only those from Papua, who had the most abnormal results, were rural villagers.

Acquisition of tropical enteropathy by travellers with adequate diet and nutrition suggests that these factors are not critical. In terms of type of diet, no differences in intestinal permeability were found between meat and vegetarian eaters among immigrants from India and the Carribbean living in Birmingham. ${ }^{23}$ It is likely, on the other hand, that reduced absorptive capacity will itself contribute to malnutrition, an important medical problem in many tropical areas, especially in those people receiving a marginal dietary intake ${ }^{34}$ and with systemic infections, as in kwashiorkor.

The sensitivity of different test monosaccharides varies considerably, depression of L-rhamnose being most and 3-0-methyl-Dglucose least with respect to comparison of tropical with European residents. This pattern is also followed in the coeliac and tropical malabsorption groups. ${ }^{5}{ }^{6}$ Fordtran and colleagues ${ }^{27}$ showed the large reserve capacity shown by the human intestine for the active mediated absorption of 3-0-methyl-D-glucose in contrast to $\mathrm{D}$-xylose, anticipating a relative insensitivity of 3-0-methyl-D-glucose to minor changes in absorption. They also found that mediated absorption of D-xylose mainly reflected jejunal function, uptake from the ileum being minimal. Absorption of L-rhamnose, however, by non-mediated diffusion equally across both jejunal and ileal surfaces, provides a more appropriate estimate of the mucosal surface available for absorption. The average 3-0methyl-D-glucose absorption in the residents of "tropical" compared with European areas was reduced by only $10 \%$, but the reduction of D-xylose by $20 \%$ and, of even more relevance, by $38 \%$ for L-rhamnose (see table 2 ), should be regarded as important and likely to predispose to malnutrition.

Geographical differences in intestinal permeability and absorption may be relevant to the predisposition to diarrhoeal illness affecting travellers and indigenous residents. Traveller's diarrhoea is a common problem among those visiting developing countries, ${ }^{37-39}$ the exact incidence varying in different regions. As noted earlier, results from the relatively affluent subjects studied suggest that travellers would also be susceptible to these factors. Impairment of drug absorption may be a further complication of potential importance. ${ }^{40}$

There are several limitations to our study. Firstly, as this was not a population based survey, mean values for sugar excretion and lactulose:rhamnose ratio for each country are to be regarded as provisional estimates, as these were not truly random samples and sample sizes were limited. Nevertheless, other studies done in Europe and North America using sugar solutions ${ }^{41}$ or ${ }^{51} \mathrm{Cr}-\mathrm{EDTA}^{34}$ have found fairly consistent results in normal volunteers as opposed to the wide variation found in the tropics. Secondly, as this was a large international study it was not possible to obtain intestinal biopsy specimens for comparison with the function tests. Furthermore, detailed workups of apparently healthy volunteers were not done so that concurrent infections (including intestinal parasitic infections) or abnormal microbial flora, could not be investigated.

In summary, using the oral administration of a multiple sugar test to apparently healthy subjects resident in both tropical and temperate countries, we have shown significant geographical variation in intestinal permeability and absorptive capacity, providing further evidence relating to the distribution of tropical enteropathy and its impact on intestinal function. These findings suggest that an association exists between intestinal function and environmental factors, probably related to local gut microbiology and general levels of hygiene and sanitation, although a role for ethnicity still needs to be thoroughly investigated. We speculate that in many tropical countries, especially where there is widespread poverty, these factors may predispose to gastrointestinal infection with frequently repeated episodes, of which many are probably subclinical, leading to a chronic though reversible impairment of intestinal function. The parameters tested in our investigation may be relevant to the predispositions of the indigenous population and travellers to diarrhoeal illness and malnutrition. Investigations of intestinal function in patients from the tropics may be difficult to interpret, but should take into account the wide range of values found in the asymptomatic normal population.

Colleagues who have helped by organising field studies are as follows: Ron Behrens, Carlo Caffarelli, Sharon Catt, ${ }^{\star}$ Richard Chasty, ${ }^{\star} \mathrm{P}$ Elliott, ${ }^{\star}$ Nick Fox, ${ }^{\star}$ Leonie Grellier, ${ }^{\star}$ Graem Houston, Talia Kakourou, $M$ Molyneux, Cathie Noone, ${ }^{\star} E$ Patterson, ${ }^{\star}$ Clare Peacock, ${ }^{\star}$ Brendan Slavin, and the staff of "Operation Drake". The authors thank Nancy A Casner for her help and Myrna Arvizo for her preparation of the manuscript. Parts of this work were presented at the meeting of the British Pociety of Gastroenterology in Dublin meeting of the British Society of Gastroenterology in Dublin, September 1989 and at the World Congress of Gastroenterology in Los Angeles, October 1994 . ( ${ }^{\star}$ Received support from the St Thomas's Hospital
Endowments Fund for Medical Student Elective Boards. All are now medically qualified.)

1 Sprinz H, Sribhibhadh R, Gangarosa EJ, et al. Biopsy of small bowel of Thai people. Am F Clin Pathol 1962;38:4351 .

2 Anonymous. The tropical intestine [editorial]. BMF 1972;1: 2-3.

3 Cook GC. Tropical gastroenterology. Oxford: Oxford University Press, 1980:271-324. 
4 Cook GC. The small intestine and its role in chronic diarrheal disease in the tropics. In: Gracey M, ed. Diarrhea. Boca Raton: CRC Press, 1991:127-62.

5 Menzies IS. Transmucosal passage of inert molecules in health and disease. In: Skadhauge E, Heintze K, eds. Intestinal absorption and secretion. Falk Symposium 36. Lancaster: MTP Press, 1984:527-43.

6 Cook GC, Menzies IS. Intestinal absorption and unmediated permeation of sugars in post-infective tropical malabsorption (tropical sprue). Digestion 1986;33:109-16.

7 Griffiths CEM, Menzies IS, Borrison I, et al. Intestinal permeability in dermatitis herpetiformis. F Invest Dermatol 1988;91:147-9.

8 Menzies IS, Turner MW. Intestinal permeation of molecules in health and disease. In: MacDonald TT, ed. Immunology of gastrointestinal disease. Vol 19. London: Kluwer Academic Publishers, 1992:173-91.

9 Travis S, Menzies I. Intestinal permeability: functional assessment and significance. Clin Sci 1992;82:471-88.

10 Bjarnason I, MacPherson A, Hollander D. Intestinal permeability: an overview. Gastroenterology 1995;108:156681 .

11 Menzies IS. Quantitative estimation of sugars in blood and urine by paper chromatography using direct densitometry. f Chromatogr 1973;81:109-27.

12 Menzies IS, Crane R. Quantitative estimation of sugars by thin-layer chromatography and scanning densitometry. Assessing intestinal absorptive capacity and permeability in vivo. In Preedy VR, Watson RR, eds. Methods in disease: investigating the gastrointestinal tract. London: Greenwich Medical Media Ltd, 1998:53-63.

13 Menzies IS, Mount JN, Wheeler MJ. Quantitative estimation of clinically important monosaccharides in plasma by rapid thin layer chromatography. Ann Clin Biochem 1978; 15:65-76.

14 The 1994 Information Please almanac, atlas, and yearbook. 47th edn. Boston: Houghton Mifflin, 1994.

15 Lindenbaum J. Small intestine dysfunction in Pakistanis and Americans resident in Pakistan. Am 7 Clin Nutr 1968;21: 1023-9.

16 Brunser O, Eidelman S, Klipstein FA. Intestinal morphology of rural Haitians. A comparison between overt tropical sprue and asymptomatic subjects. Gastroenterology 1970; 58:655-68.

17 Schenk EA, Klipstein FA, Tomasini JT. Morphologic characteristics of jejunal biopsies from asymptomatic Haitian and Puerto Ricans. Am $\mathcal{F}$ Clin Nutr 1972;25:1080-3.

18 Falaiye JM. Present status of subclinical intestinal malabsorption in the tropics. BMF 1971;4:454-8.

19 Lindenbaum J, Harmon JW, Gerson CD. Subclinical malabsorption in developing countries. Am f Clin Nut 1972;25:1056-61.

20 Lindenbaum J, Kent TH, Sprintz H. Malabsorption and jejunitis in American Peace Corps Volunteers in Pakistan. Ann Intern Med 1966;65:1201-9.

21 Sheehy TW, Legters LJ, Wallace DK. Tropical jejunitis in Americans serving in Vietnam. Am 7 Clin Nutr 1968;21: American

22 Wood GM, Gearty JC, Cooper BT. Small bowel morphology in British Indian and Afro-Caribbean subjects:
evidence of tropical enteropathy. Gut 1991;32:256-9.

23 Iqbal TH, Lewis KO, Gearty JC, et al. Small intestinal permeability to mannitol and lactulose in the three ethnic groups resident in West Birmingham. Gut 1996;39:199203.
24 Klipstein FA, Falaiye JM. Tropical sprue in expatriates from the tropics living in the continental United States. Medicine 1969;48:475-91.

25 Gerson CD, Kent TH, Saha JR, et al. Recovery of small intestinal structure and function after residence in the tropics. II. Studies in Indians and Pakistanis living in New York City. Ann Intern Med 1971;75:41-8.

26 Ukabam SO, Homeida MMA, Cooper BT. Small intestinal permeability in normal Sudanese subjects: evidence of tropical enteropathy. Trans R Soc Trop Med Hyg 1986;80: 204-7.

27 Fordtran JS, Clodi PH, Soergel KH, et al. Sugar absorption tests, with special reference to 3-0-methyl-D-glucose and D-xylose. Ann Intern Med 1962;57:883-91.

28 Peled Y, Watz C, Gilat T. Measurement of intestinal permeability using ${ }^{51}$ Cr-EDTA. Am 7 Gastroenterol 1985;80:770-

29 Ford RPK, Menzies IS, Phillips AD, et al. Intestinal sugar permeability: relationship to diarrhoeal disease and small bowel morphology. F Pediatr Gastroenterol Nutr 1985;4:56874.

30 Weaver LT, Chapman PD, Madeley CR, et al. Intestinal permeability changes and excretion of micro-organisms in stools of infants with diarrhoea and vomiting. Arch Dis Child 1985;60:326-32.

31 Noone C, Menzies IS, Banatvala JE, et al. Intestinal permeability and lactose hydrolysis in human rotaviral gastroenteritis assessed simultaneously by non-invasive differential sugar permeation. Eur f Clin Invest 1986;16:217-25.

32 Isolauri $E$, Juntunen $M$, Wiren $S$, et al. Intestinal permeability changes in acute gastroenteritis: effects of clinical factors and nutritional management. $\mathcal{F}$ Pediatr Gastroenterol Nutr 1989;8:466-73.

33 Forget P, Sodoyez-Goffaux F, Zappitelli A. Permeability of the small intestine to ${ }^{51} \mathrm{Cr}$-EDTA in children with acute gastroenteritis or eczema. F Pediatr Gastroenterol Nutr 1985; 4:393-6.

34 Zuckerman MJ, Watts MT, Bhatt BD, et al. Intestinal permeability to ${ }^{51} \mathrm{Cr}-\mathrm{EDTA}$ in infectious diarrhea. Dig Dis Sci 1993;38:1651-7.

35 Lim SG, Menzies IS, Lee CA, et al. Intestinal permeability and function in patients infected with human immunodeficiency virus. Scand f Gastroenterol 1993;28:573-80.

36 Keating J, Bjarnason I, Somasundaram S, et al. Intestinal absorptive capacity, intestinal permeability and jejunal histology in HIV and their relation to diarrhoea. Gut 1995;37: 623-9.

37 Steffen R. Epidemiologic studies of travelers' diarrhea, severe gastrointestinal infections, and cholera. Rev Infect Dis 1986;8(suppl 2):S122-30.

38 DuPont HL, Ericsson CD. Prevention and treatment of traveler's diarrhea. $N$ Engl F Med 1993;328:1821-7.

39 DuPont HL, Capsuto EG. Persistent diarrhea in travelers. Clin Infect Dis 1996;22:124-8.

40 Behrens RH, Taylor RB, Los AS, et al. Traveller's diarrhea: a controlled study of its effect on chloroquine and proguanil absorption. Trans R Soc Trop Med Hyg 1994;88:86-8.

41 Bjarnason I, Levi S, Smethhurst P, et al. Vindaloo and you. BMf 1988;297:1629-31. 